\title{
Reclamation of a Saline-Sodic Soil by Use of Molasses and Distillery Slops
}

\author{
Raúl p'érez E'scolar \\ INTRODUCTION
}

Reclamation of saline, and saline-sodic soils low in organic mater constilutes a potential najor problem in many areas of the wordd. Removal of soluble salts by leaching from a soil high in free salls and low in exchangeable sodium may result in the formation of solonetzic horizons at lower depths by a mass-action effect. Similarly, the removal of frec salts from a soil with a relatively high content of exchangeable sodium may result; in the formation of sodic layers in the entire profile. The increase in the electrokinetic potential by the enkanced dissociation of the hydrated sodium ions results in the dispersion of the soil colloids with the corresponding clogging up of soil pores which creates poor air: water relations.

\section{REVIEW OF LITERATURE}

An intensive search of the literature revealed that not a single attempt. had been made to use rum distillery slops as a soil ammendmen to improve structural conditions in saline-sodic and sodic soils. This may be because most distilleries discharge this waste-product directly into the oceans and rivers.

Dhar and Mukerji (2) appear to be the only investigators who conducted experimental work using blackstrap molasses to help reclaim solonetzic soils. They clain to have brought these soils back to "normal conditions" in a period of 6 months when molasses was applied at the rates of 30 to 40 tous to the acre. They believed that their results wero produced by the acidity of molasses and the organic acids such as acetic, propionie, bulyric, and lactic, produced upon decomposition of the molasses. There acted to neutralize the bases and carbonates present in soil rich in alkali. It was also proposed that, in the process, the evolution of $\mathrm{CO}_{2}$ from the molassestreated soil rendered it porous and improved its tilth. It was observed that microbial activity, which is normally low at the prevailing $\mathrm{pH}$ of sodic soils, was considerably increased. Soil nitrogen content was increased from 0.0025 to 0.05 percent. This increase in soil nitrogen was caused by grenter fixation of atmospheric nifrogen by micro-organisms.

1 Associate Soil Scientist, $\Lambda$ gricultural Experiment Station, University of Puerto Rico, Río Piedras, P.R.

2 Italic numbers in parentheses refer to Literature Cited, p. 217. 


\section{MATERIALS ANI MUTHODS}

The soil used in this experiment was a saline-sodic lo day of southwestern Puerto Rico. It is associated with other soils of the alluvial fans in the semiarid sections from Boqueron to Guatuma. The surfues soil in a cultivated field is a grayish-brown granular calcareous day, very plastic when wot and either gramular or eloddy when dry, deponding on the moisture condition

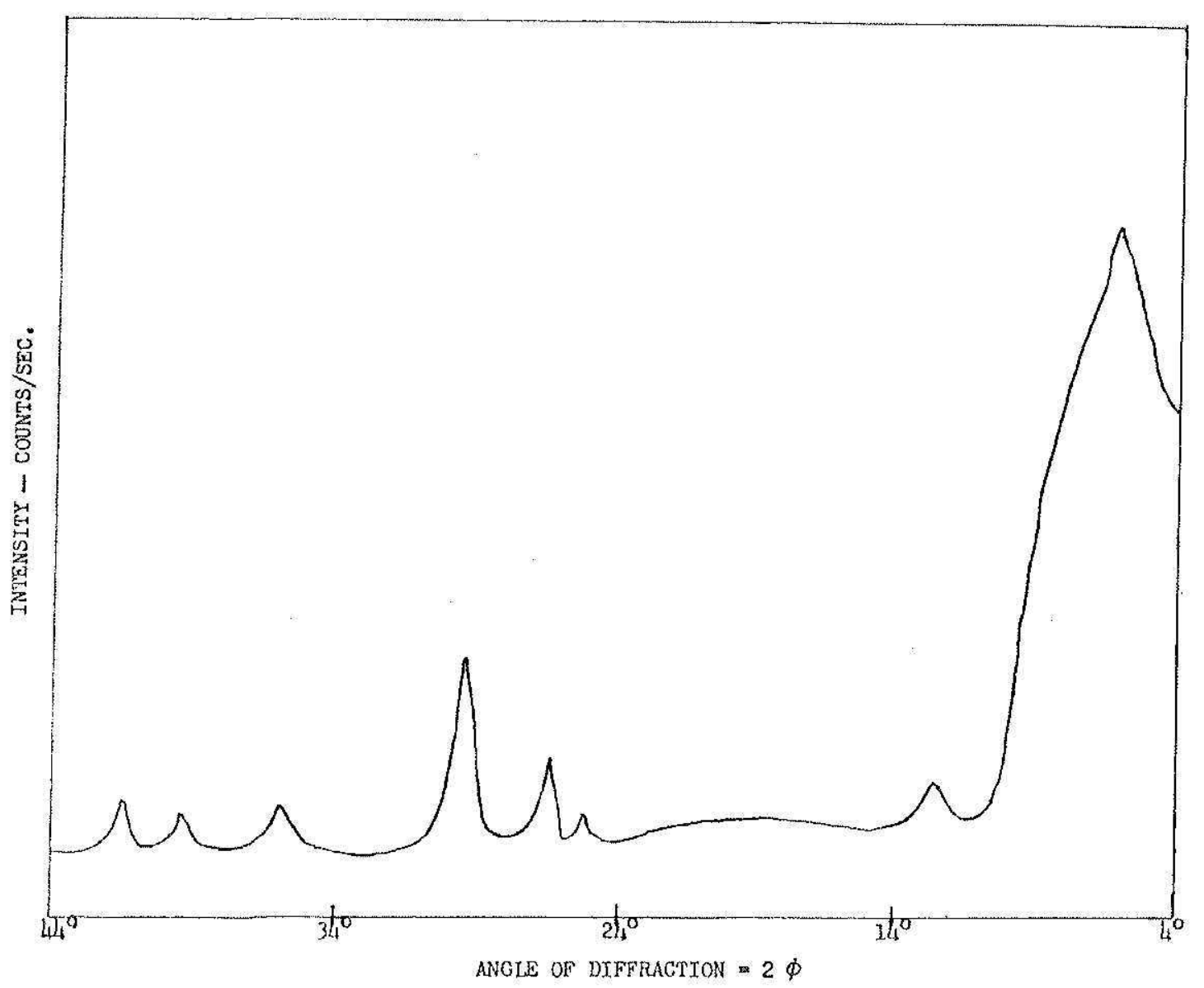

Fra. 1.- X-rey diffrelogram of elay fraction of Fe soil.

of the soil when plowed. The subsoil, to a depth of approximately 20 inches, is light pinkish-brown or purplish-brown plastic calcareous medium-rompact columnar elay. Montmorillonile, as shown in fig. 1, is the predominant (lity mineral in the soil colloidal fraction. Foolinite and quartz are found in traces.

This soil was 43-pereent sodimm-saturaled and the conductivity of the saturation extruct of the soil was 67 mmhos per centimeter. The soil was broken up with a wooden rolling-pin and aggregates of 2 - to 1 -mm, size were separated. Seven hundred and fifty grams of these aggregates wore 
placed in glass tubes of $13 / 4$-inch interior dimmeter and 24 inches long. 'To insure unitorm soil-packing, the colums wore subjected to a vibrating mathine for 1 minute. The following troutments, in duplicale, wore established:

1. Control.

2. A third of soil column wetted with slops.

3. 'Two-thirds of soil column wetted with slops.

4. The whole soil column wetted with slops.

5. A third of the soil column wetled with 25 perent by volume of blackstraj) molisses.

6. The whole soil eolumn wetted with 25 percent by volume of blackstrul molasses.

lixactly 1 day alter the treatments were applied 3.4 inches of tapwater were added to the soil columns. Thereafter, the columns were watered every other day at this mite. After each foot of water had been pasised through the column, the leachate was collected and the following mensure. ments were made: 1 , Volume of leachate; $2, \mathrm{pH} ; 3$, specific conductance; and 4 , sodium, enleium, and magnesium contents.

When 6 feet of walcr had been passed through the columns, the soil lubes did not receive any additional waler for 1 month. This was done to detemine whether a drying period would alter the effects produced by use of blackstrap molases and of distillery slops. When this period was ended watering was resumed as before.

After a total of 12 feet of water had been passed through the columns, the soils were taken out undisturbed and ent into sections 5 inches long. The following measurements were made on these seetions: $1,1, \mathrm{H} ; 2$, saturation pereentage; 3, specific conductanes of the saluration extract; and 4 , content of exchangeable sodium and calcium and magnesium in the sacuralion extract.

The pH of the lenchates and of the soil was determined clectrometrically, employing a Beckman jH-meter. Calcium and manesium contents of leachates were determined by the E.D.'L.A. method (1). Specific resistance of the saturation extracts and of the leachates was determined with a Wheatstone bridge using a cell with a constant of 1 . Electrical conductivity was calculated by multiplying the measured negative resistance by the coll constant. Exchangeable sodium was determined by plotting the values of soluble Ca, $\mathrm{Mg}$, and Na into a nomogram.

Soil organic matter was detcrmined by the chromic arid reduction method (6). Cation-exchange capacity of the soil was delermined by the baxium acetate method (/).

Particle-size distribution was determined by the pipette method, as modified by Kilmer and Alexander (3). 
The minerals present in the soil colloidal fraction were determined using an RCA-I ciments Crystalloflex IV X-ray diffactometer with an automatic recording device.

\section{RESULTS AND DISCUSSION}

This reclamation experiment in the laboratory was a complete success and the results of these studies and the characteristics of the lie clay soil

\begin{tabular}{|c|c|c|c|c|c|c|}
\hline Foot No. & Check & Low slops & Medium slops & Higls slops & Low molasses & High molasses \\
\hline 1 & 169.53 & 291.35 & 259.98 & $270.26 j$ & 224.28 & $27 \overline{3} .27$ \\
\hline 2 & 55.98 & 65.10 & 42.49 & 42.02 & 73.09 & 47.72 \\
\hline 3 & 15.89 & 18.97 & 15.08 & 13.91 & 15.01 & 10.78 \\
\hline 4 & 11.35 & 14.42 & 14.02 & 10.66 & 12.52 & 8.28 \\
\hline 5 & 7.65 & 10.35 & 8.74 & 8.18 & 8.73 & 3.49 \\
\hline 6 & 5.80 & 8.76 & 7.50 & (i. 58 & 6.06 & $4.4 \pi$ \\
\hline 7 & 8.33 & 8.77 & $0.7 !$ & 4.10 & 4.79 & 1.64 \\
\hline 8 & 7.98 & 6.40 & 3.99 & 2.30 & 4.02 & 1. $f(6$ \\
\hline 9 & 6.78 & 4.42 & 2.13 & 1. 24 & 2.27 & 1.04 \\
\hline 10 & 3.24. & 3.59 & .63 & .45 & .91 & .92 \\
\hline 11 & 2.17 & 2.87 & .31 & .32 & .33 & .38 \\
\hline 12 & 1.88 & 2.02 & .23 & .23 & .23 & .36 \\
\hline
\end{tabular}

are presented in tables 1 through 5 , and in the following tabulation, showing some chemieal and physical data on the Fe clay soil:

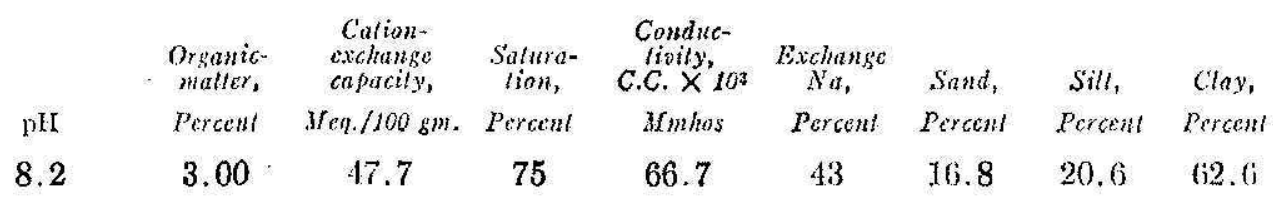

All soil columns treated with slops or molasses at the end of the test exhibited excellent drainage characteristics. The first 3 acreffeet of water passed through the trealed soil columns removed approximalely 92 percent of the exchangeable, or free sodium salts present. Complete wetting of the soil columns with either slops or molasses, followed by irrigation, yielded leachates that contained more calcium and magnesium than those under all of the other treatments. As was the ease with sodium, the bulk of the $\mathrm{Ca}$ and $\mathrm{Mg}$ was also removed by the first 3 acre-feet of irrigation water passed through these columns.

That most $\mathrm{Ca}$ and $\mathrm{Mg}$ was found in leachates of columns treated with the highest level of the slops or molasses may have occured because of 
the production of organic acids during the decomposition of both slops and molasses. 'These organic acids rendered soluble the $\mathrm{CaCO}_{3}$ and $\mathrm{MgCO} \mathrm{CO}_{3}$ present in the soil. The recovery of applied water varied with the treut-
TABue 2.--Calcium content of leachates collected during the percolation of tis fect of water through soil columens treated with distillery slops or molasses (meq pr? leachate) at difforent levels

\begin{tabular}{|c|r|r|r|r|r|r|}
\hline Foot No. & Check & Low slops & Medium slops & High slops & Low molisses & High molasses \\
\hline 1 & 14.61 & 15.17 & 29.63 & 49.96 & 26.53 & 47.82 \\
2 & 2.03 & 2.59 & 1.13 & 2.29 & 3.16 & 11.25 \\
3 & .81 & .89 & .50 & .53 & .70 & 1.32 \\
4 & .79 & .88 & .88 & .64 & .99 & 1.74 \\
5 & .37 & .29 & .27 & .42 & .46 & 1.61 \\
6 & .18 & .23 & .32 & .65 & .43 & 1.28 \\
7 & .19 & .25 & .24 & .50 & .38 & 1.54 \\
8 & .16 & .21 & .37 & .35 & .45 & 1.12 \\
9 & .17 & .16 & .37 & .43 & .62 & .96 \\
10 & .11 & .08 & .46 & .48 & .58 & 1.12 \\
11 & .12 & .17 & .46 & .44 & .59 & 1.11 \\
12 & .11 & .53 & .64 & .40 & .62 & 1.05 \\
\hline
\end{tabular}

TARLE 3.--Maynesizm content of leachates collected during the pereolation of 12 jert. of water through soil columns treated with distillery slops or molesses (meq. per leachate) al diferent levels

\begin{tabular}{c|r|r|r|r|r|r}
\hline Foot No. & Check & Low slops & Medium slops & Irigh slops & Low molasses & righ molasses \\
\hline 1 & 29.22 & 35.77 & 64.27 & 84.55 & 41,07 & 95.04 \\
2 & 7.31 & 8.23 & 4.86 & 7.65 & 12.31 & 18.20 \\
3 & .80 & .65 & .77 & .92 & .94 & 3.43 \\
4 & .75 & .58 & .96 & .96 & 1.26 & 2.12 \\
5 & .83 & .98 & .60 & .89 & .70 & .97 \\
6 & .64 & .32 & .34 & .93 & .86 & 1.17 \\
7 & .55 & .32 & .42 & 1.49 & .46 & 1.56 \\
8 & .24 & .19 & .30 & 1.07 & .49 & 1.25 \\
9 & .17 & .08 & .75 & 1.25 & .71 & 1.27 \\
10 & .13 & .07 & 1.56 & 1.36 & .94 & 1.12 \\
11 & .13 & .15 & 1.33 & 1.40 & 1.15 & 1.48 \\
12 & .29 & .68 & 1.30 & 1.34 & 1.20 & 1.23 \\
\hline
\end{tabular}

nents, and ranged from 84 to 92 percent with the slops and molasses treatments, respectively. The water recovered from the control treatment amounted to only 51. percent of that applied.

During the course of the experiment the infiltration rates of water on the slops and molasses treatments were very satisfactory. Although infiltration rates were not detcrmined, observations indicated that the rate for the 
poorest treatment was about 1 inch per hour, even after 12 feet of water had been applied. 'This estimalo would have been higher if a constant head of water had been maintained in the soil column.

The average pH values of the leachates of all teatments after the passage of the 12 feet of water ranged from 8 to 9 . These high ph values indicate the removal of alkaline salis such as $\mathrm{Na}_{2} \mathrm{CO}_{3}, \mathrm{CaCO}_{3}$, and $\mathrm{MgCO}_{3}$.

As will be shown in a forthcoming publiation, the active soil-aggregating fraction of the slops dissolves at high $\mathrm{pH}$ values, and it would not seem logical that its eflects would be so long-lasting in these soils, when the relatively high $\mathrm{pH}$ values of the percolating waters are considered. However, it is possible that the presenee of high quantilies of free Ta salts may have reduced its solubility. Further dehydration of the active material

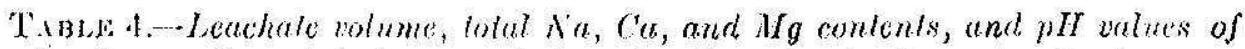

lsathates collected ruring pereotation of 12 feot of water through soil columns trealed with distillery slops or molosses al difterent levels ${ }^{1}$

\begin{tabular}{|c|c|c|c|c|c|c|}
\hline Treatinent & $\begin{array}{l}\text { Average } \mathrm{H}_{2} \mathrm{O} \\
\text { deliverced per } \\
\text { acre-foot }\end{array}$ & $\begin{array}{l}\text { Water } \\
\text { recovered in } \\
\text { leachates }\end{array}$ & $\mathrm{Nit}$ & $\mathrm{Ca}$ & $\mathrm{M}_{\mathrm{s}}$ & $\begin{array}{c}\text { pH of } \\
\text { leathates }\end{array}$ \\
\hline & $C c$. & l'creent & Meq. & Meil. & $M(t)$ & \\
\hline Clleck & 239.33 & 51.03 & $296 j .67$ & 19.65 & 11.06 & 9.0 \\
\hline Iox sops & 100.00 & 85.16 & 302.64 & 21.43 & 17.51 & 8.9 \\
\hline Medium slops: & 416.29 & 88.76 & 301.88 & 35.26 & 77.42 & 8.5 \\
\hline Jrigh slops & $121 i .00$ & 90.84 & 3660.29 & 57.48 & 103.77 & 8.3 \\
\hline Low molitises & +11.38 & 87.72 & 353.14 & 35.50 & 077.07 & 8.3 \\
\hline Iligh molasses & 430.25 & 91.74 & 356.31 & 71.80 & 129.41 & 8.0 \\
\hline
\end{tabular}

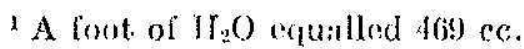

may be involved. It should be pointed out that dehydration is not only attained by using hest to drive off moisture, but it can also be arhieved when salts are present in large quantities. This reaction is like the "saltingout" phenomenon assoriated with chemical precipitation of proteins. Dehydration phenomena have been considered for a long lime to be an integral tactor involved in the stabilization of soil aggregates.

'The unireated soil columns underwent some reclamation in the upper' part, but the lower layers, although losing some exchangeable sodium, still contained enough markedly to retard water movement. It should also be pointed out that, when water was applied to the control columus, it required around 1.0 days to collect 3.4 inches of percolate, amounting to a recovery of about one-half. Apparently water loss by evaporation was high from the top of the column, since only 51 percent of the applied water was recovered. Water infiltration was observed to decrease with time in the 
check treatments, which (an be explained by the dispersive action of sodium adsorbed by the soil.

The finet that the adsorbed sodium was partly removed from the top

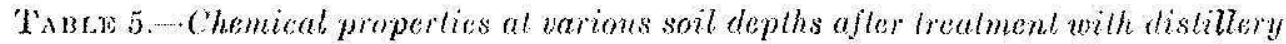
slops or molasses, and tho percolation of 12 feel of waler

\begin{tabular}{|c|c|c|c|c|c|c|c|c|}
\hline \multirow{3}{*}{ 'Treatment } & \multicolumn{5}{|c|}{ Saturation extract } & \multicolumn{3}{|c|}{ Soil } \\
\hline & \multirow{2}{*}{$\begin{array}{l}\text { Depth } \\
\text { In. }\end{array}$} & \multirow{2}{*}{$\begin{array}{l}\text { Silura- } \\
\text { tion } \\
\text { Percent }\end{array}$} & \multirow{2}{*}{ 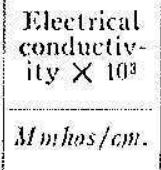 } & \multirow{2}{*}{$\mid \begin{array}{c}\mathrm{Ca}+\mathrm{Mg} \\
\mathrm{Meq} \cdot \mathrm{ll}\end{array}$} & \multirow{2}{*}{$\begin{array}{l}\text { Nil } \\
\text { Meq./l. } \\
\text { r. }\end{array}$} & \multirow[t]{2}{*}{ i) $\mathrm{H}$} & \multicolumn{2}{|c|}{ Exchangeable sodium } \\
\hline & & & & & & & Mcq.thots & Percent \\
\hline \multirow[t]{4}{*}{ Cherk } & 0.5 & 82 & 1.00 & 0.70 & 3.30 & 8.4 & 0.72 & 1.51 \\
\hline & $5-10$ & 82 & 1.33 & 6.70 & 6.60 & 8.4 & 1.92 & 4.00 \\
\hline & $10-15$ & 102 & 3.00 & 3.67 & 26.33 & 8.9 & $15 .-12$ & 32.13 \\
\hline & 1520 & 111 & 2.00 & 1.94 & 18.06 & 9.1 & 14.88 & 31.00 \\
\hline \multirow[t]{4}{*}{ Low slops } & $0-5$ & 78 & 1.25 & 9.51 & 2.95 & 8.2 & .29 & .60 \\
\hline & $5 \cdots 10$ & 82 & .79 & 5.98 & 1.91 & 8.2 & .23 & .48 \\
\hline & 1015 & 89 & .72 & 5.00 & 2.21 & 8.2 & .27 & .57 \\
\hline & $15-20$ & 88 & .76 & 5.30 & 2.31 & 8.4 & .31 & 1.02 \\
\hline \multirow[t]{4}{*}{ Medium slops } & 0.5 & 81 & 1.13 & 8.35 & 2.91 & 8.1 & .25 & .53 \\
\hline & $5-10$ & 92 & .65 & 4.43 & 2.08 & 8.2 & .22 & .45 \\
\hline & $10-15$ & 85 & 1.02 & 7.70 & 2.46 & 8.2 & .20 & .41 \\
\hline & 1520 & 85 & .75 & 6.08 & 1.43 & 8.2 & .24 & .50 \\
\hline \multirow[t]{4}{*}{ High slops } & $0 \cdots 5$ & 81 & 1.58 & 12.10 & 3.166 & 8.0 & .29 & .61 \\
\hline & 6- 10 & 80 & .81 & 5.72 & 2.38 & 8.0 & .22 & .47 \\
\hline & $10-15$ & 80 & 82 & 4.92 & 3.29 & 8.1 & .23 & .40 \\
\hline & $15-20$ & 83 & 1.11 & $7.51 i$ & 3.51 & 8.1 & .33 & 69 \\
\hline \multirow[t]{4}{*}{ Low mulasses } & $0 \div 5$ & 81 & 1.62 & 12.48 & 3.73 & 8.0 & .35 & .72 \\
\hline & $5-10$ & 80 & .71 & 5.02 & 2.08 & 8.0 & $.26 j$ & .55 \\
\hline & $10-15$ & 80 & .96 & 7.29 & 2.26 & 8.1 & .27 & .67 \\
\hline & $15-20$ & 81 & 1.14 & 8.70 & 2.71 & 8.0 & .20 & (i) \\
\hline \multirow[t]{4}{*}{ High molusses } & 05 & 83 & 1.89 & 14.15 & 4.75 & 8.0 & .29 & $.6 !$ \\
\hline & $5-10$ & 82 & 1. 20 & 7.78 & 4.83 & 8.0 & .26 & .55 \\
\hline & $10-1 \tilde{0}$ & 86 & 1.21 & 7.51 & 4.60 & $7.4)$ & .35 & .74 \\
\hline & $15-20$ & 87 & 1.17 & 6.01 & 5.01 & 8.0 & .33 & .00 \\
\hline
\end{tabular}

layers of the check treatment, can be explained by the eflects of soluble $\mathrm{NaCl}$ on the solubility of $\mathrm{Ca}$ and $\mathrm{MgCO}_{3}$. It is known that the solubility of these salts is greatly increased in the presenee of NaCl. The addition of ocean water, high in $\mathrm{NaCl}$, has proved to be a bencficial practice in the 
reclamation of sodic soils, so long as the soils contain free $\mathrm{CaCO}_{3}(5)$. This praclice, however, presupposes the additions of this water with decreasing $\mathrm{NaCl}$ as rechmation progresses.

After the sixth acre-foot of water had been passed through the columns, a whole month was allowed to pass before any more water was applied. This did not exert any apparent eftect on the infiltration rates of water which had been previously noted.

When the cores were sectioned for analyses, an excellent stable soil structure was found in all molasses and slops treatments when compared with the highly dispersed controls.

\section{SUMMARY}

Data are presented on a laboratory study conducted to delermine the effects of the use of blackstrap molasses and rum distillery slops on the reclamation of a highly saline-alkali heavy clay soil of southwestern Pucrto Rico.

The study revealed that even the lowest levels of distillery slops and diluted molasses, around 2.3 acre-inch, were sufficient to lower the conductivity of the soil-saturation extract from $67 \mathrm{mmhos} / \mathrm{cm}$, to less than 3 , and the exchangeable sodium percentage from 13 to less than 1 percent.

It is believed that most of the Cand Mfr found in leachates of columns treated with the most slops or molasses may be attributed to the production of organic acids during the decomposition of slops and molasses. These organis acids rendered soluble the soil-free $\mathrm{CaCO}_{3}$ and $\mathrm{MgCO}_{3}$, widening the Ca and Mg: Na ratio to substitute the sodium by a mass action effect.

Subjecting the soil to a dry period in between the 6 and 7 acre-feet of water did not alter the movement of water and resulted in a complete soil reclamation."

\section{RLSUMEN}

Se presentan los datos de $u$ estudio de tabomtorio para deleminar la acción de las mieles finales y los mostos de destilerías sobre la restauración de un suelo areilloso con un alto contenido de sales y sodio intercambiables.

Fil estudio revoló que aúm los niveles más bajos de mosto y miel diluída, en Ia proximidad de 2.3 acre-pulgadas, bastaron para bajar la conductividad del extracto de saturación del suelo, de 67 mmhos/cm. a menos de 3 mmhos/ ('m, y el sodio intercambiable de 43 por ciento a menos de 1 por eiento.

Se eree que el hecho de que las cantidades más altas de Ca y Mrg apare-

3 Trade names are used in this publication solely for the purpose of providing specific information. Mention of a trade name does not, constitute a guarantee, warranty, or endorsement by the Agricultural Experiment Station indicating or implying superiority to other similar products not mentioned, 
rienan on las aguas de filtanción de las rolummas que contenían altos niveles de mosto y micl, se deba a la acrón disolvente de los ácidos orgánicos que

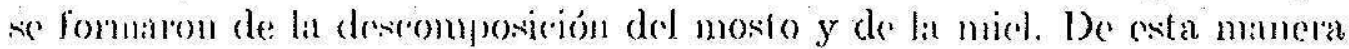

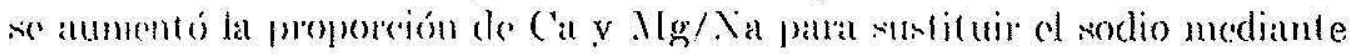
Lula acrión rat matisi.

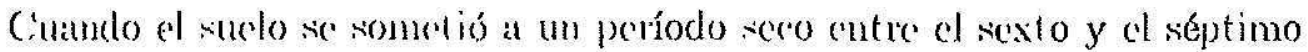
areve-pie de agua, no hubo alteración en el movimiento del agua, resultando

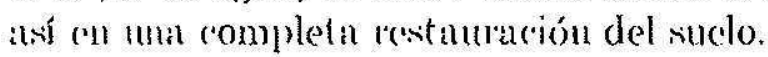

\section{DATERA'TURE CITEEO)}

1. ('bon, K. and Bray, R. H., Detemination of calcium and matgnesium in soil and plant matcriat, Soil Sci. 72: $+19-58,1951$.

2. I) .1 cerd. Sci., Ludia, pp. 133i +8. 1936i.

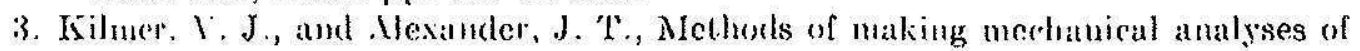
soils, suil Sci. 68: 15-24, 1919.

4. Parker, l. W., The determination of exchangeable hydrogen in soils, J. Imer. Suc. Ligron. 21: 1030-39. 102?).

5. liceve, R. C., and Bower, C. A., (se of high-salt waters as a floceulant and source of divalcut, cations for reclaiming sudic soils, Soil Sci, 90; 139-43, 1960.

(i. Valkley, A., and Blake, T. A., An examination of the Degtjarelf method for determining soil organic matter and proposed modification of the chromic acid reductiou methed, Soil sici. 37: 29) 38, 1934. 